Fisheries Research

September 2017, Volume 193 Pages 207-216

http://dx.doi.org/10.1016/i.fishres.2017.04.013

http://archimer.ifremer.fr/doc/00384/49553/

(c) 2017 Elsevier B.V. All rights reserved.

\title{
Improving gear selectivity of whiting (Merlangius merlangus) on board French demersal trawlers in the English Channel and North Sea
}

\author{
Vogel Camille ${ }^{1,2,{ }^{*}, \text { Kopp Dorothee }}{ }^{1}$, Morandeau Fabien ${ }^{1}$, Morfin Marie ${ }^{1}$, Méhault Sonia ${ }^{1}$
}

${ }^{1}$ IFREMER, Department of Biological Resources and Environment, Fisheries Science and Technology Research Unit, Laboratory for Fisheries Technologies and Fish Biology (RBE/STH/LTBH), 8 rue François Toullec, F-56100 Lorient, France

2 IFREMER, Department of Biological Resources and Environment, Fisheries Science for the English Channel and North Sea, Fisheries Resources Laboratory, Avenue du Général de Gaulle, F-14520 Porten-Bessin-Huppain, France

* Corresponding author : Camille Vogel, email address : camille.vogel@ifremer.fr

\begin{abstract}
:
In the English Channel and Southern Bight, French demersal trawlers target a mix of demersal species including whiting (Merlangius merlangus). The discard ban to be implemented in January 2016 motivated fishermen to look for technical measures to reduce unwanted catches of undersized individuals $(<27 \mathrm{~cm})$. From 2008-2014, 18 different gear configurations were tested for bycatch reduction on board fleets of vessels of $16-20 \mathrm{~m}$ and 20-24 m. Selective devices tested included grids, square mesh panels (SMP), square mesh cylinders (SMC), various combinations of these devices and large mesh trawls. Using the catch comparison method, our results focus on six devices that proved efficient to reduce catches of undersized whiting, equally divided between the two vessel size groups. Large mesh trawls are not adequate to improve whiting size selectivity with losses of commercial size fish. The mandatory 80-mm SMP was efficient at letting undersized whiting escape from the trawl for both vessel length classes. Its efficiency was enhanced when it was positioned 6-9 $\mathrm{m}$ ahead of the codline compared with that placed at $12-15 \mathrm{~m}$. The most appropriate bar spacing for whiting sizeselectivity was found in a flexigrid with $23 \mathrm{~mm}$ bar spacing, but this required a large portion of square mesh netting to be installed ahead of it (SMP and SMC) to limit catches of undersized individuals. The most promising device tested was an $80 \mathrm{~mm}$ SMC, either $2 \mathrm{~m}$ long and used alone or $1 \mathrm{~m}$ long and used in association with the mandatory SMP; these setups allowed significant escapes of fish up to $25 \mathrm{~cm}$ in length. For both SMP and SMC, a mesh size equal to or larger than $100 \mathrm{~mm}$ led to losses of commercial size whiting.
\end{abstract}




\section{Highlights}

- This work deals with gear selectivity for whiting on board French demersal trawlers in the English Channel and Southern Bight. Six selective gear configurations with positive effect on whiting escape were tested between 2008 and 2014. Trials included square mesh panels, square mesh cylinders, grids, different device associations and large mesh trawls. The 2-m long, 80-mm square mesh cylinder allowed the escape of whiting $\leq 25 \mathrm{~cm}$ long without losses of commercial size fish.

Keywords: Square mesh, Sorting grids, Fishing gear technology, Merlangius merlangus, Catch comparison, GLMM

\section{Introduction}

The new Common Fisheries Policy includes the obligation to land all fish captured in all European fisheries where an exemption has not been granted (EU, 2013). Discarding is closely linked to the ability of a given gear to avoid unwanted catches (Kelleher, 2005). Exemptions will be decided on a 
species- and fishery-specific basis, where fleets can demonstrate that all potential measures to reduce discards have been implemented (EC, 2013). To minimize the impact of the landing obligation for professional fishermen, gear selectivity needs to be improved to reduce unwanted bycatch, especially of commercial species under specific legislation due to stock depletion or of individuals below the minimum landing size (MLS) (Graham, 2006; Madsen and Valentinsson, 2010; Sacchi, 2008).

Vessels using bottom trawls have been subjected to the landing obligation from January 2016. Bottom trawling for demersal species is one of the most common fishing métiers and was estimated to account for up to $50 \%$ of all discards worldwide (Kelleher, 2005). The selective properties of bottom trawls have been studied extensively over the years, leading to the development of new mesh configurations, selective grids, escape windows, sorting boxes and innovative trawl designs (Catchpole and Gray, 2010; Catchpole and Revill, 2008; Suuronen, 2008). The use of some selective devices is already legally enforced in some European fisheries, with good results for stock recovery, such as northern European hake (Baudron and Fernandes, 2015; EC, 2004; ICES, 2013) and North Sea $\operatorname{cod}$ (EC, 2008; Kraak et al., 2013).

Whiting (Merlangius merlangus, Linnaeus 1758) is one of the species for which the discard ban applies. Under the current legislation, this species has a MLS of $27 \mathrm{~cm}$ and fishing is limited by annual total allowable catch (TAC). In the North Sea area, whiting is targeted as part of a multispecific demersal fishery together with other whitefish species such as cod (Gadus morhua) and haddock (Melanogrammus aeglefinus) (Catchpole et al., 2007; Depestele et al., 2014; Ferro et al., 2007). It is also recognised as the prevalent bycatch of demersal trawlers targeting Nephrops (Enever et al., 2009).

When caught in a trawl, whiting is known to rise to the top part of the extension and codend sections, with good escape success if the fish makes contact with the netting (Holst et al., 2009; Krag et al., 2009). Early work on size selectivity for whiting already identified square mesh panels (SMPs) 
as a potential mitigating measure to reduce catches of undersized individuals (Briggs, 1992). Since 2001, the use of a SMP inserted up-front from the codend in the dorsal extension piece of the trawl is mandatory for all trawlers over $18 \mathrm{~m}$ working in the North Sea and Southern Bight (EC, 2001, 1998). A previous study found an $18 \%$ reduction in discards of whiting with the addition of the mandatory SMP for English and Welsh otter trawlers in the North Sea (Enever et al., 2009). Discards of whiting and other gadoid species in the North Sea have fallen since 2000, although the reasons for this trend involve the interrelated effects of declining stock biomass and the implementation of mitigation measures (Heath and Cook, 2015). Different SMP configurations continue to be studied in an effort to improve gadoid selectivity (Bullough et al., 2007; Drewery et al., 2010; Sardà et al., 2004).

French demersal trawlers working in the English Channel and Southern Bight operates on fishing grounds in the ICES Divisions IVc, IVd and VIId. In 2013, whiting accounted for $30 \%$ of all landings and $27 \%$ of all discards of French demersal trawlers over $18 \mathrm{~m}$ in length (Cornou et al., 2015). Undersized discarded whiting have limited survival capacity due to their low stress tolerance (see review by Davis, 2002) and physiological specificities (Depestele et al., 2014). Exemption from landing obligation would therefore only be considered if there was improved size selectivity, which can be achieved through fishing gear modifications, as previously carried out in some North Sea demersal multi-specific fisheries (Graham et al., 2007).

To date, apart from SMPs, other selective devices considered to reduce bycatch of undersized whiting include selective grids (Drewery et al., 2010; Eigaard et al., 2012), horizontal separator panels (Ferro et al., 2007), large mesh trawls (Campbell et al., 2010), the use of various mesh geometries in the codend (Frandsen et al., 2010) and combinations of grids and square mesh codends (Valentinsson and Ulmestrand, 2008). The influence of a vessel's technical specifications is not usually considered however, limiting the extrapolation of results to fleets with identical characteristics. 
The catch comparison technique tests the efficiency of a modified, more selective gear (the test gear) compared to a gear deployed traditionally by the fishing vessel (the control gear) (Millar, 1992; Millar and Fryer, 1999). Analysis of catch comparison datasets has evolved from length-class catch comparisons by t-test (Armstrong et al., 1998) to non-parametric methods (Fryer et al., 2003). More recently, Holst and Revill (2009) introduced generalized linear mixed models (GLMM) as a means of "[obtaining] a pragmatic and reliable curve for the expected proportions-at-length" for a test codend compared with a commercial codend. Using this technique, over-dispersion and correlation are accounted for by integrating the dataset's structure in the modelling process (Breslow and Clayton, 1993; Holst and Revill, 2009).

In the present study, we used the catch comparison method (Briggs, 1992) to test the efficiency of a number of selective devices for reducing bycatches of whiting in 16-20 and 20-24 m long French demersal trawlers working in the ICES Divisions IVb, IVc and VIId. For each fleet, selective devices with similar settings were tested. Based on previous results obtained from grids and for SMPs on whiting size selectivity, combinations of different selective devices were also considered in an attempt to increase undersized fish escape from the trawl gear. Analyses were carried out following the approach developed by Holst and Revill (2009).

\section{Material and methods}

\subsection{Sea Trials}

From 2008 to 2014, gear selectivity trials were conducted in the English Channel and in the Southern Bight area focusing on French trawlers of 16-20 m and 20-24 m targeting local demersal species. They aimed to identify mitigating measures that could reduce bycatch of undersized whiting on vessels of 20-24 m, to develop selective devices to avoid catches of large cod for both vessel length classes following the new legislation enforced in 2009 (EC, 2009), and to add to knowledge gained during previous experiments in the context of the discard ban implementation. 
Trials were conducted on 18 different configurations including: (i) grids with either horizontal (grid H) or vertical bars (grid V), of different materials (i.e. flexigrids made of polyurethane and aluminium grids) and four bar spacings ( $20 \mathrm{~mm}, 23 \mathrm{~mm}, 30 \mathrm{~mm}$ and $90 \mathrm{~mm}$ ), (ii) SMPs of four different mesh sizes ( $25 \mathrm{~mm}, 60 \mathrm{~mm}, 80 \mathrm{~mm}$ and $120 \mathrm{~mm}$ ) and rigged at four different distances from the codline (12 m, $6 \mathrm{~m}, 18 \mathrm{~m}$ and $21 \mathrm{~m}$ on the top panel), (iii) square mesh cylinders (SMC) of three different mesh sizes ( $80 \mathrm{~mm}, 100 \mathrm{~mm}, 115 \mathrm{~mm}$ ) and two different lengths (either 1 or 2 -m long), (iv) a trawl integrating large mesh sections, and ( $v$ ) other combinations of these devices. The analysis focus on six configurations which demonstrated efficient selective properties. They are equally distributed between vessels over and under $20 \mathrm{~m}$ in length.

Detailed technical configurations, sampling period and fishing area for each of these six selective devices are given for vessels of 20-24 m and 16-20 m in Table 1. Each configuration was given a specific gear reference number. These were a flexigrid $V$ with 20-mm bar spacing (Gear 1), a large mesh trawl (Gear 2) and the 80-mm SMP with 80-mm SMC of $1 \mathrm{~m}$ (Gear 3) for 20-24 m vessels; and a 60-mm SMP with two consecutive grids (Gear 4), a 80-mm SMC of $2 \mathrm{~m}$ (Gear 5), and the combination of a 80-mm SMC of $2 \mathrm{~m}$ with an aluminium grid $\mathrm{V}$ with 23-mm bar spacing (Gear 6) for 16-20 $\mathrm{m}$ vessels. Schematic representations of the different devices are added for ease of reading (Figure 1) except for the large mesh trawl, for which its design is detailed (Figure 2). Gear 2 for vessels 20-24 m long and Gear 4 for vessels $16-20 \mathrm{~m}$ long were initially designed to select for large cod. The number of hauls run with each specific gear is given as a measure of the overall sampling effort. So as to ensure that trial results were representative of the size selectivity properties of the gear, all gears were tested through more than 10 tows.

All codends were made of 80-mm diamond mesh netting. For 20-24 m long vessels, the control gears were equipped with the mandatory 80-mm SMP, as enforced by the Cod Recovery Plan in the North Sea (EC, 2008). This SMP is $3 \mathrm{~m}$ by $1 \mathrm{~m}$ in size and is located in the dorsal extension part of the trawl, 
right behind the tapered section. For $16-20 \mathrm{~m}$ long vessels, the control gears had no associated selective devices.

Experiments were set up following the parallel haul method (Wileman et al., 1996). Two commercial fishing vessels with least differences in size and horsepower were selected from each size group (16$20 \mathrm{~m}$ and 20-24 m long). Vessels were equipped with new, identical trawls aside of the selective devices added, to ensure that the catch is representative in both the test and the control vessels. Trawl design for gear selectivity trials was identical to commercial trawls used in the area, their design being specific to each vessels' length class (Figure 3 for vessels $16-20 \mathrm{~m}$ long, and Figure 4 for vessels 20-24 m long). Mesh size of both the codend and SMP were measured with gauge prior to each trial.

For each selective device tested, one vessel was rigged with the control gear while the second one used the test gear. For each pair of hauls, the test and the control vessel launched and hauled back the gear at the same time, and followed paths as parallel as possible. To limit bias that could still arise from differences between the two vessels, such as variations in towing speed or in gear adjustments, they switched "control" and "test" roles every two hauls or every 24 hours.

\subsection{Haul selection}

To ensure that paired-haul data analysis would apply, good parallelism was used as a criterion for haul selection prior to analysis: the maximum angle between two paired hauls was set at $20^{\circ}$, to account for variability arising from experimental conditions. Records where the difference in distance between two paired hauls was greater than $7.8 \mathrm{~km}\left(0.1\right.$ decimal degree at $50^{\circ} \mathrm{N}$ of latitude) were equally dismissed. Hauls were omitted if damage to the gear was noted in either the control or the test. 
Data collection was carried out following the official French protocol for scientific observers at sea (Badts et al., 2010). For each haul, environmental conditions, location, depth, gear settings, and time of gear deployment and retrieval were recorded. Both the commercial and non-commercial fractions of the catches were sampled. Total fish length $(\mathrm{cm})$ per individual, and weight $(\mathrm{kg})$ per species and per fractions of the catch were recorded. When the total catch was too large to allow measurement of every individual, random sub-sampling was performed and the weight ratio between total catch and subsample was recorded for further data processing.

\subsection{Data selection}

The weight ratio of the subsample to the total catch was missing for 12 records of fish from 28 to 33 $\mathrm{cm}$. The empirical distribution of the weight ratio was computed for all records in the same length class. A random value was then sampled from this empirical distribution for each of the 12 incomplete records. Outliers were deleted based on individual length: records were deleted when the measured value was smaller than the $0.25^{\text {th }}$ quantile of the overall length values' distribution. For each haul, length classes where less than five individuals were measured, for the sum of the control and test codend, were deleted as they were unrepresentative of the effect of the gear being tested.

\subsection{Statistical analysis}

All statistical analyses were run with R (R Core Team, 2014). Pooled upscaled count data were plotted for each selective device against the corresponding control gear, creating catch comparison graphs. Distributions of catches by the test and the control gears were checked for identity based on the Kolmogorov-Smirnov test (K-S test). Proportions of fish per length class, $\mathrm{P}(\mathrm{l})$, were computed and displayed on the graph, such that:

$$
P(l)=\frac{N_{l, t}}{N_{l, c}+N_{l, t}}
$$


with $\mathrm{N}_{\mathrm{l}, \mathrm{t}}$ the total count of fish of length $\mathrm{l}$ in the test gear and $\mathrm{N}_{\mathrm{l}, \mathrm{c}}$ the total count of fish of length $\mathrm{l}$ in the control gear. A weighted spline regression with four degrees of freedom was run on the observed proportions and added to the graph.

Data analysis was carried out with logistic regression in the GLMM framework, according to Holst and Revill's methodology (2009) and traditional data analysis of binomial data type (Agresti, 2010). Mixed models allow users to account for variability arising from the experimental design by adding random terms to the model's structure that will affect either or both the intercept and the slope parameter estimates (Pinheiro and Bates, 2000). The response variable consisted of raw count data, and subsampling was accounted for by implementing an offset term in the model. Fish length, date and time of day (i.e. night, dawn, day and dusk) were considered as explanatory variables, with "haul" being implemented as the random term. Fish length was standardized to facilitate model convergence. Centring (L-mean) and scaling (L-sd) parameters for length were reported to make estimate interpretation in GLMM results easier. Having a random intercept takes into account that the baseline escape probability varies from one haul to another, which can be interpreted as the effect of environmental and/or external conditions on catches. We further designated these as the "sampling conditions". A random slope implies that escape probability varies for fish of the same length class between hauls, which could be due to individual fitness differences, for example.

Although natural variability in fish escape probability for the same length class is theoretically sound, here it was not considered to allow for comparison of our results with previously published literature on the same subject.

GLMM were set using the Ime4 R package with the glmer() function (Bates et al., 2016). For each device, a backwards selection procedure based on AIC was applied to select explanatory variables (Burnham and Anderson, 2002; Vaida and Blanchard, 2005).The model equation was therefore:

$$
\operatorname{logit}\left(\frac{\mathrm{N}_{\text {Test }}}{\mathrm{N}_{\text {Control }}+\mathrm{N}_{\text {Test }}}\right)=\log \left(\frac{\mathrm{q}_{\mathrm{Test}}}{\mathrm{q}_{\text {Control }}}\right)+\beta_{0, \mathrm{j}}+\sum_{\mathrm{i}=1}^{\mathrm{m}} \beta_{\mathrm{i}} \mathrm{X}_{\mathrm{i}}+\varepsilon_{\mathrm{j}} \text {, with } \varepsilon_{\mathbf{j}} \sim \mathrm{N}\left(0, \sigma_{\mathrm{j}}\right)
$$


Where $\mathrm{q}_{\mathrm{Test}}$ and $\mathrm{q}_{\text {Control }}$ are the subsampling ratio for the fraction measured, is are the constant terms in the model (i.e. the length covariates, date and time of day) and js are the different levels of the random factor that will account for additional variance being explained by the model (i.e. hauls). For splines and GLMM results, the horizontal line drawn at 0.5 is the level at which both gears fish equally. An efficient selective device will hereafter designate a device for which the 0.5 level is not reached for small sized individuals $(<27 \mathrm{~cm})$ but is either equal to or greater than 0.5 for individuals larger than $27 \mathrm{~cm}$. Such a pattern corresponds to an escape of undersized individuals without losses of commercial size fish on the catch. Some tolerance of up to $3 \mathrm{~cm}$ under the MLS $(27 \mathrm{~cm})$ when reaching the 0.5 level is allowed to qualify a device as efficient.

\section{Results}

Results are presented by vessel length class, since control gears were specific to each.

\subsection{Catch composition}

Catches were mostly composed of two size classes, with individuals larger than $30 \mathrm{~cm}$, and individuals between 20 and $30 \mathrm{~cm}$ in length (Figure 5). Size classes are more distinct in 16-20 m long vessels (Figure 5. Gears 4 to 6). A third size class of smaller individuals $(0-20 \mathrm{~cm})$ can be identified as well, though less sampled by the gears. Our results do not cover the entire length range of the species, with a limited number of individuals recorded over $40 \mathrm{~cm}$ in length.

Devices tested on vessels of $16-20 \mathrm{~m}$ have a more pronounced effect on fish $\leq 30 \mathrm{~cm}$ than those tested on vessels of 20-24 m (Figure 5). Fish caught by vessels of 16-20 m are smaller on average than individuals caught by larger vessels. The variability in fish length is similar for both vessel length classes (Table 2). 
GLMM results show that natural variability arising from the sampling conditions of each haul has an impact on escape corresponding to variability around the mean value for a given fish length (Figure 6). The large-mesh trawl has the least effect on fish escape of the six presented devices, although it is also the gear of least variability. "Date" and "time of day" did not improve the fit of the model. Only "length" was kept as explanatory variable with a fixed effect.

\subsection{Vessels $20-24 \mathrm{~m}$ long}

Average haul depth was equal to $42 \mathrm{~m}$, with a minimum value of $21 \mathrm{~m}$ and a maximum of $71 \mathrm{~m}$. The test and control gears sampled the same fish population (Figure 5 and Table 2. Gears 1 to 3). The population sampled by the large mesh trawl appears bimodal, while the other two configurations show unimodal catch distributions. Large sample sizes are recorded for all devices, with the maximum number of individuals caught for a given length class ranging from 5000 up to 12000 in the control gear and from 3000 to 8000 in the test gear (Figure 5. Gears 1 to 3).

The trends underpinned by the regressive splines on weighted proportions correspond properly to GLMM for the three devices (Figure 6. Gears 1 to 3). The ability of GLMM to account for variability arising from the sampling process is particularly well illustrated for the large mesh trawl; Although individuals under $15 \mathrm{~cm}$ in length were more abundant in the test codend across trials, the GLMM overrides this sampling artefact due to overall small number of fish in these sizes and produces a curve that predicts generally lower catches in the test gear than in the control gear for this length range (Figure 5 and Figure 6. Gears 1 to 3). Parameters estimates and associated standard errors are reported for the three models (Table 3. Gears 1 to 3). device was efficient at letting fish under $23 \mathrm{~cm}$ and over $36 \mathrm{~cm}$ in length escape. The catches of individuals from $23 \mathrm{~cm}$ to $36 \mathrm{~cm}$ in the test gear were identical to or higher than those of the control gear although the variability was greater for these middle length classes. The large mesh trawl (Gear 2) was efficient over almost the entire whiting length range, although only very slightly for fish 
between 27 and $34 \mathrm{~cm}$ in length. The large mesh trawl has a limited influence above that size. It is the gear of least variability. The 80-mm SMP with $80-\mathrm{mm} \mathrm{SMC} \mathrm{of} 1 \mathrm{~m}$ (Gear 3) is most efficient for the escape of individuals under $26 \mathrm{~cm}$ in length and has a mitigated influence above that size, with average catch probability by test gear being less than 0.5 , but with a $95 \%$ confidence interval $(\mathrm{Cl})$ overlapping the 0.5 line.

\subsection{Vessels $16-20 \mathrm{~m}$ long}

Average haul depth was equal to $40 \mathrm{~m}$, with a minimum value of $16 \mathrm{~m}$ and a maximum of $64 \mathrm{~m}$. The maximum number of individuals caught for a given length class ranged from 250 to 4200 in the control gear and from 90 to 1500 in the test gear (Figure 5. Gears 4 to 6). Length distributions of the populations sampled by the test and control gears are not statistically different for Gears 4 and 5 , and statistically different for Gear 6 (Table 2). Of the six devices presented in our results, this is the only gear setting tested that was sampling over a different fish length distribution than its control.

All three selective gears display a strong effect on the escape of fish under $30 \mathrm{~cm}$ in length (Figure 6 . Gears 4 to 6). The 60-mm SMP with two consecutive grids (Gear 4) allows fish to escape over their entire length range. The remaining two gears ( 5 and 6 ) display a similarly shaped selective profile. The 2-m long $80-\mathrm{mm} \mathrm{SMC} \mathrm{(Gear} \mathrm{5)} \mathrm{is} \mathrm{efficient} \mathrm{at} \mathrm{letting} \mathrm{fish} \mathrm{under} 23 \mathrm{~cm}$ escape, with little variability around the mean estimate, while the latter configuration allows significant escape up to $31 \mathrm{~cm}$, with greater variability around the mean value. Parameter estimates and associated standard errors are reported for the three models (Table 3. Gears 4 to 6).

\section{Discussion}

Whiting from the eastern English Channel and Southern Bight belong to the same population (de Castro et al., 2013) and reach a maximum adult size of $50 \mathrm{~cm}$. Despite variations in cohort strength and representation in our data, results of $\mathrm{K}-\mathrm{S}$ tests suggest that five out of the six selective devices 
presented have an effect on the overall length class of whiting, with varying size effect across the fish length range. However, our study focuses more particularly on reducing discards of undersized individuals $(<27 \mathrm{~cm})$ while preserving catches of commercial sizes. From our results, whiting escape appears to be unaffected by the time of day, as observed by Eigaard et al. (2012). These results are in favour of an opportunistic escape behaviour rather than an active one, as demonstrated by Jones et al. (2008). Variability arising from environmental conditions such as depth, wind speed or water temperature were not explicitly accounted for in our models but contribute to the overall variability observed.

\subsection{Square Mesh Panels}

No additional escapement of undersized whiting could be obtained in the different SMP trials run on 20-24 m trawlers. These results highlight two properties of SMP for whiting size-selectivity. First, the increase in mesh size, from the mandatory $80 \mathrm{~mm}$ SMP to SMP with $120 \mathrm{~mm}$ mesh size, does not benefit small individuals, which would escape through the existing $80-\mathrm{mm}$ square mesh anyway, but instead would allow more commercial size fish to escape. Second, the addition of a SMP in the tapered section does not increase escape possibilities for whiting, as already observed by Campbell et al. (2010) when using 300-mm diamond mesh in the forward section of a trawl. This suggests that whiting is not able to escape through selective devices located too far-up in the trawl body once caught, which could be due limited swimming abilities. However, our results suggest that the implementation of a mandatory SMP rigged in the dorsal part of the extension piece on board smaller boats would reduce catches of undersized whiting (Bullough et al., 2007; Catchpole and Revill, 2008).

\subsection{Selective grids}

In our experiments, grids were considered alone or in association with other selective devices, whether this was a SMP, SMC or second grid. We obtained different results in efficacy of grids for different vessel sizes. Only the 2-m long $80-\mathrm{mm} \mathrm{SMC}$ with a $30-\mathrm{mm}$ aluminium grid $\mathrm{V}$ on board $16-20$ 
$\mathrm{m}$ long vessels (Figure 6, Gear 6) leads to the escape of most fish under $20 \mathrm{~cm}$ in length, is efficient at letting fish up to $30 \mathrm{~cm}$ in length escape and would not induce losses of commercial size fish.

Many parameters need to be considered to understand the differences in the effect of grids on whiting size-selectivity. They could arise from the grid material (aluminium frame or flexigrid), difference in bar spacing or, as previously acknowledged, from the presence of the mandatory SMP in the control gear for larger vessels. Variations in selectivity from the use of different materials have been reported by Valentinsson and Ulmerstrand (2008), who considered that less stable bar spacing could lead to less efficient devices. The rigid aluminium grid tested during our trial shows better selective properties than any of the tested flexigrid and would lead to similar conclusions. However, the difference in bar spacing ( $7 \mathrm{~mm}$ larger for the aluminium grid) must also contribute to the variations observed between grids.

Regarding the use of two grids, it should be remembered that these configurations are designed for large cod to escape (Gear 4). The double grid system on 16-20 m vessels was kept as a successful configuration, although it increases escape over the whole length range of the species (Figure 6, Gear 4). Such a configuration would only be of interest in cases of drastic TAC reduction or stock collapse. Likewise, the $20 \mathrm{~mm}$ flexigrid $\mathrm{V}$ used on board 20-24 m vessels would provide a way to limit catches of whiting over $36 \mathrm{~cm}$ in length (Figure 6, Gear 1).

\subsection{Square mesh cylinders}

There are no references to devices similar to SMC in the published literature, making it difficult to compare our results with those of other devices currently in use. The innovative SMCs show promising results in reducing catches of undersized individuals. Out of the three mesh sizes tested, the 80-mm SMC provides a good profile of escape for both vessel sizes, allowing small fish to escape but retaining large ones. The 2-m long $80-\mathrm{mm} \mathrm{SMC}$ tested on board vessels $16-20 \mathrm{~m}$ in length is the most efficient device presented in our study, allowing significant escape of fish up to $25 \mathrm{~cm}$ in length 
with the mandatory SMP on board of vessels of 20-24 m (Figure 6, Gear 3) allows significant escape

338 of whiting up to $26 \mathrm{~cm}$.

The remaining trials of SMCs, rigged either alone (SMC $100 \mathrm{~mm}$ and SMC $115 \mathrm{~mm}$ ) or in association with a SMP (SMC $80 \mathrm{~mm}$ 2-m length + SMP $80 \mathrm{~mm}$ 3-m length) or with a selective grid (SMC $80 \mathrm{~mm}+$ grid V $23 \mathrm{~mm}$ ), were inconclusive on whiting escape. These configurations mostly induced losses of larger, commercial size fish. As concluded for SMP, the use of square mesh of $100 \mathrm{~mm}$ or larger in SMC is not appropriate for selective fishing for whiting.

\subsection{Large mesh trawl}

The large mesh trawl appears unsuited for selective fishing for whiting, unlike the good results obtained on other gadoid species such as cod from trawls with comparable settings (Beutel et al., 2008). While similar configurations have been tested for both vessel sizes, the large mesh trawl is only efficient for those of 20-24 m, but would trigger losses on commercial size fish over $35 \mathrm{~cm}$ in length (Figure 6, Gear 2). The difference in the selective properties of this gear between different vessel sizes is unclear. However, the difference in sampling effort dedicated to each fleet ( 38 valid trawls for vessels of 20-24 m, 12 for those of 16-20 m) may play a role in the representativeness of

352 the population sampled in the trials.

\subsection{Implications for the discard ban policy}

With the implementation of the discard ban to demersal trawlers starting January 2016, and the possibilities for fisheries-specific exemptions, gear selectivity faces a new challenge that goes beyond the more traditional stock management approach (Condie et al., 2014; Sardà et al., 2015). In the Barents Sea and in the North Sea, the earlier implementation of such a regulation led to the adoption of selective gears by most Norwegian commercial fishermen, and enhanced further collaboration between scientists and commercial fishermen to guarantee the sustainable exploitation of stocks

360 (Graham et al., 2007). However, selection and implementation of selective gears must be made through careful steps to be successful, ensuring that the new legislation is attractive enough to get 
commercial fishermen's approval (Suuronen and Sardà, 2007; Uhlmann et al., 2014). Likewise, Rochet et al. (2014) recommended that technical measures such as selective fishing gears be implemented together with behavioural changes in fishermen's habits.

The different programs conducted in the English Channel and Southern Bight area between 2008 and 2014 compose a strong and coherent dataset to assess the efficiency of different selective devices and gear designs, looking to achieve the best compromise between preserving commercial catches and reducing discards. The trials analysed for this study were run in association with members of the fishing industry, who are proactively seeking technologies to mitigate their impact on whitefish populations and looking to implement sustainable fishing practices. It is expected that devices identified as efficient for undersized whiting escape by scientists during these trials, such as SMC, would become popular among commercial fishermen as they require relatively simple trawl modifications and limited alteration of gear handling at sea.

Catchpole et al. (2005) consider that the discard ban would put an additional pressure on populations already highly exploited and recommend that reducing captures of unwanted individuals must be the main objective, rather than looking for commercial utilization of discards. The experiments run on board French demersal trawlers in the English Channel and Southern Bight highlight the efficiency of mandatory measures already in place in the area (80-mm SMP) at letting undersized whiting escape from a trawl. Evolving from traditional SMP, the trials run on the use of SMC proved highly successful; their implementation would mitigate the consequences of the discard ban for the fishing industry by reducing catches of undersized whiting. Moreover, based on previous case studies from the North Atlantic region, Condie et al. (2014) state that measures such as a discard ban will only be successful if landings of unwanted catches are discouraged. Selective devices are therefore critical tools for both fishermen and legislators in the development of a wider management system to achieve sustainable fishing in European waters.

\section{Acknowledgments}


Data collection was carried out as part of three French research programs: SELECMER, SELECCAB and SELECFISH. These programs were funded by the Comité National des Pêches Maritimes et des Elevages Marins, the Comité Régional des Pêches Maritimes et des Elevages Marins du Nord Pas de Calais-Picardie, the Regional Council of Nord Pas de Calais, France Filière Pêche and through the European funding scheme. Data analysis and publication were financed by the Direction des Pêches Marines et de l'Aquaculture. The authors wish to thank Bruno Ernande and Franck Coppin of IFREMER Boulogne-sur-Mer for their help on data collection and analysis.

\section{References}

Agresti, A., 2010. Logistic Regression, in: Analysis of Ordinal Categorical Data. John Wiley \& Sons, pp. 163-209.

Armstrong, M.J., Briggs, R.P., Rihan, D., 1998. A study of optimum positioning of square-mesh escape panels in Irish Sea Nephrops trawls1. Fish. Res. 34, 179-189. doi:10.1016/S01657836(97)00078-7

Bates, D., Maechler, M., Bolker, B., Walker, S., 2016. Ime4: Linear mixed-effects models using Eigen and S4, CRAN-R project. ed., https://CRAN.R-project.org/packages/Ime4/Ime4.pdf.

Baudron, A.R., Fernandes, P.G., 2015. Adverse consequences of stock recovery: European hake, a new "choke" species under a discard ban? Fish Fish. 16, 563-575. doi:10.1111/faf.12079

Breslow, N.E., Clayton, D.G., 1993. Approximate Inference in Generalized Linear Mixed Models. J. Am. Stat. Assoc. 88, 9-25. doi:10.1080/01621459.1993.10594284

Briggs, R.P., 1992. An assessment of nets with a square mesh panel as a whiting conservation tool in the Irish Sea Nephrops fishery. Fish. Res. 13, 133-152. doi:10.1016/0165-7836(92)90023-M

Bullough, L.W., Napier, I.R., Laurenson, C.H., Riley, D., Fryer, R.J., Ferro, R.S.T., Kynoch, R.J., 2007. A year-long trial of a square mesh panel in a commercial demersal trawl. Fish. Res. 83, 105112. doi:10.1016/j.fishres.2006.09.008 
Burnham, K.P., Anderson, D.R., 2002. Model Selection and Multimodel Inference: A Practical Information-Theoretic Approach. Springer Science \& Business Media, p. 488.

Campbell, R., Harcus, T., Weirman, D., Fryer, R.J., Kynoch, R.J., O'Neill, F.G., 2010. The reduction of cod discards by inserting $300 \mathrm{~mm}$ diamond mesh netting in the forward sections of a trawl gear. Fish. Res. 102, 221-226. doi:10.1016/j.fishres.2009.12.001

Catchpole, T.L., Frid, C.L.J., Gray, T.S., 2005. Discards in North Sea fisheries: causes, consequences and solutions. Mar. Policy 29, 421-430. doi:10.1016/j.marpol.2004.07.001

Catchpole, T.L., Gray, T.S., 2010. Reducing discards of fish at sea: a review of European pilot projects. J. Environ. Manage. 91, 717-723. doi:10.1016/j.jenvman.2009.09.035

Catchpole, T.L., Revill, A.S., 2008. Gear technology in Nephrops trawl fisheries. Rev. Fish Biol. Fish. 18, 17-31. doi:10.1007/s11160-007-9061-y

Catchpole, T.L., Tidd, A.N., Kell, L.T., Revill, A.S., Dunlin, G., 2007. The potential for new Nephrops trawl designs to positively effect North Sea stocks of cod, haddock and whiting. Fish. Res. 86, 262-267. doi:10.1016/j.fishres.2007.06.023

Condie, H.M., Grant, A., Catchpole, T.L., 2014. Incentivising selective fishing under a policy to ban discards; lessons from European and global fisheries. Mar. Policy 45, 287-292. doi:10.1016/j.marpol.2013.09.001

Cornou, A.-S., Dimeet, J., Tetard, A., Gaudou, O., Quinio-Scavinner, M., Fauconnet, L., Dube, B., Rochet, M.-J., 2015. Observations à bord des navires de pêche professionnelle. Bilan de l'échantillonnage 2013. Ifremer.

Davis, M.W., 2002. Key principles for understanding fish bycatch discard mortality. Can. J. Fish. Aquat. Sci. 59, 1834-1843. doi:10.1139/f02-139

de Castro, C., Wright, P.J., Millar, C.P., Holmes, S.J., 2013. Evidence for substock dynamics within whiting (Merlangius merlangus) management regions. ICES J. Mar. Sci. J. Cons. 70, 11181127. doi:10.1093/icesjms/fst027 
Depestele, J., Desender, M., Benoît, H.P., Polet, H., Vincx, M., 2014. Short-term survival of discarded target fish and non-target invertebrate species in the "eurocutter" beam trawl fishery of the southern North Sea. Fish. Res. 154, 82-92. doi:10.1016/j.fishres.2014.01.018

Drewery, J., Bova, D., Kynoch, R.J., Edridge, A., Fryer, R.J., O'Neill, F.G., 2010. The selectivity of the Swedish grid and $120 \mathrm{~mm}$ square mesh panels in the Scottish Nephrops trawl fishery. Fish. Res. 106, 454-459. doi:10.1016/j.fishres.2010.09.020

EC, 2013. Position of the Council at first reading with a view to the adoption of a Regulation of the European Parliament and of the Council on the Common Fisheries Policy, amending Council Regulations (EC) No 1954 / 2003 and (EC) No 1224 / 2009 and repealing Council Regulations.

EC, 2009. Council Regulation (EC) No 43/2009 of 16 January 2009 fixing for 2009 the fishing opportunities and associated conditions for certain fish stocks and groups of fish stocks, applicable in Community waters and, for Community vessels, in waters where catch limitations are required.

EC, 2008. Council Regulation (EC) No 1342/2008 of 18 December 2008 establishing a long-term plan for cod stocks and the fisheries exploiting those stocks and repealing Regulation (EC) No 423/2004, Official Journal of the European Union.

EC, 2004. Council Regulation (EC) No. 811/2004 of 21.4.2004 establishing measures for the recovery of the Northern hake stock, Official Journal of the European Union.

EC, 2001. Commission Regulation (EC) No 2056/2001 of 19 October 2001 establishing additional technical measures for the recovery of the stocks of cod in the North Sea and to the west of Scotland. Off. J. Eur. Communities L 277, 13-16.

EC, 1998. Council Regulation (EC) No 850/98 of 30 March 1998 for the conservation of fishery resources through technical measures for the protection of juveniles of marine organisms. Off. J. Eur. Communities L 125, 1-36. 
Eigaard, O.R., Herrmann, B., Rasmus Nielsen, J., 2012. Influence of grid orientation and time of day on grid sorting in a small-meshed trawl fishery for Norway pout ( Trisopterus esmarkii ). Aquat. Living Resour. 25, 15-26. doi:10.1051/alr/2011152

Enever, R., Revill, A.S., Grant, A., 2009. Discarding in the North Sea and on the historical efficacy of gear-based technical measures in reducing discards. Fish. Res. 95, 40-46. doi:10.1016/j.fishres.2008.07.008

EU, 2013. Regulation (EU) no 1380/2013 of the european parliament and of the council of 11 december 2013 on the common fisheries policy, amending council regulations (EC) no $1954 / 2003$ and (EC) no 1224/2009 and repealing council regulations (EC) no 2371/2002 and (EC) no 639/2004 and council decision 2004/585/EC.

Ferro, R.S.T., Jones, E.G., Kynoch, R.J., Fryer, R.J., Buckett, B.-E., 2007. Separating species using a horizontal panel in the Scottish North Sea whitefish trawl fishery. ICES J. Mar. Sci. J. Cons. 64, 1543-1550. doi:10.1093/icesjms/fsm099

Frandsen, R.P., Madsen, N., Krag, L.A., 2010. Selectivity and escapement behaviour of five commercial fishery species in standard square- and diamond-mesh codends. ICES J. Mar. Sci. J. Cons. doi:10.1093/icesjms/fsq050

Fryer, R.J., Zuur, A.F., Graham, N., 2003. Using mixed models to combine smooth size-selection and catch-comparison curves over hauls. Can. J. Fish. Aquat. Sci. 60, 448-459. doi:10.1139/f03029

Graham, N., 2006. Trawling: Historic Development, Current Status and Future Challenges. Mar. Technol. Soc. J. 40, 20-24. doi:10.4031/002533206787353231

Graham, N., Ferro, R.S.T., Karp, W.A., MacMullen, P., 2007. Fishing practice, gear design, and the ecosystem approach - three case studies demonstrating the effect of management strategy on gear selectivity and discards. ICES J. Mar. Sci. J. Cons. 64, 744-750. doi:10.1093/icesjms/fsm059 
Heath, M.R., Cook, R.M., 2015. Hind-Casting the Quantity and Composition of Discards by Mixed Demersal Fisheries in the North Sea. PLoS ONE 10, e0117078. doi:10.1371/journal.pone.0117078

Holst, R., Ferro, R.S., Krag, L.A., Kynoch, R.J., Madsen, N., 2009. Quantification of species selectivity by using separating devices at different locations in two whitefish demersal trawls. Can. J. Fish. Aquat. Sci. 66, 2052-2061.

Holst, R., Revill, A., 2009. A simple statistical method for catch comparison studies. Fish. Res. 95, 254-259. doi:10.1016/j.fishres.2008.09.027

ICES, 2013. Report of the ICES-FAO Working Group on Fishing Technology and Fish Behaviour (WGFTFB) (ICES CM 2013/SSGESST:11). ICES, Copenhagen, Denmark.

Jones, E.G., Summerbell, K., O'Neill, F., 2008. The influence of towing speed and fish density on the behaviour of haddock in a trawl cod-end. Fish. Res., Haddock Conservation, Harvesting and Management Haddock 2007: International Symposium on Haddock Conservation, Harvesting and Management 94, 166-174. doi:10.1016/j.fishres.2008.06.010

Kelleher, K., 2005. Discards in the world's marine fisheries: an update (FAO Fisheries Technical Paper No. 470). Food \& Agriculture Org., Rome, Italy.

Kraak, S.B.M., Bailey, N., Cardinale, M., Darby, C., De Oliveira, J.A.A., Eero, M., Graham, N., Holmes, S., Jakobsen, T., Kempf, A., Kirkegaard, E., Powell, J., Scott, R.D., Simmonds, E.J., Ulrich, C., Vanhee, W., Vinther, M., 2013. Lessons for fisheries management from the EU cod recovery plan. Mar. Policy, Social and cultural impacts of marine fisheries 37, 200-213. doi:10.1016/j.marpol.2012.05.002

Krag, L.A., Madsen, N., Karlsen, J.D., 2009. A study of fish behaviour in the extension of a demersal trawl using a multi-compartment separator frame and SIT camera system. Fish. Res. 98, 6266. doi:10.1016/j.fishres.2009.03.012 
Madsen, N., Valentinsson, D., 2010. Use of selective devices in trawls to support recovery of the Kattegat cod stock: a review of experiments and experience. ICES J. Mar. Sci. J. Cons. 67, 2042-2050. doi:10.1093/icesjms/fsq153

Millar, R.B., 1992. Estimating the Size-Selectivity of Fishing Gear by Conditioning on the Total Catch. J. Am. Stat. Assoc. 87, 962-968. doi:10.2307/2290632

Millar, R.B., Fryer, R.J., 1999. Estimating the size-selection curves of towed gears, traps, nets and hooks. Rev. Fish Biol. Fish. 9, 89-116. doi:10.1023/A:1008838220001

Pinheiro, J.C., Bates, D.M., 2000. 6. Nonlinear Mixed-Effects Models: Basic Concepts and Motivation Examples and 7. Theory and Computational Methods for Nonlinear Mixed-Effects Models, in: Mixed-Effects Models in S and S-PLUS. Springer Science \& Business Media, pp. 273-336.

R Core Team, 2014. R: A Language and Environment for Statistical Computing. R Foundation for Statistical Computing, Vienna, Austria.

Rochet, M.-J., Catchpole, T., Cadrin, S., 2014. Bycatch and discards: from improved knowledge to mitigation programmes. ICES J. Mar. Sci. J. Cons. 71, 1216-1218. doi:10.1093/icesjms/fsu039

Sacchi, J., 2008. The use of trawling nets in the Mediterranean. Problems and selectivity options, in: Basurco, B. (Ed.), The Mediterranean Fisheries Sector. A Reference Publication for the VII Meeting of Ministers of Agriculture and Fisheries of CIHEAM Member Countries (Zaragoza, Spain, 4 February 2008), Options Méditerranéennes : Série B. Etudes et Recherches. Zaragoza : CIHEAM / FAO / GFCM, pp. 87-96.

Sardà, F., Coll, M., Heymans, J.J., Stergiou, K.I., 2015. Overlooked impacts and challenges of the new European discard ban. Fish Fish. 16, 175-180. doi:10.1111/faf.12060

Sardà, F., Moli, B., Palomera, I., 2004. Preservation of juvenile hake (Merluccius merluccius, L.) in the western Mediterranean demersal trawl fishery by using sorting grids. Sci. Mar. 68, 435-444.

Suuronen, P., 2008. Effectiveness and Applicability of Technical Measures in Bycatch Management, in: American Fisheries Society Symposium. AMERICAN FISHERIES SOCIETY, p. 1311. 
Suuronen, P., Sardà, F., 2007. The role of technical measures in European fisheries management and how to make them work better. ICES J. Mar. Sci. J. Cons. 64, 751-756.

Uhlmann, S.S., Helmond, A.T.M. van, Stefánsdóttir, E.K., Sigurđardóttir, S., Haralabous, J., Bellido, J.M., Carbonell, A., Catchpole, T., Damalas, D., Fauconnet, L., Feekings, J., Garcia, T., Madsen, N., Mallold, S., Margeirsson, S., Palialexis, A., Readdy, L., Valeiras, J., Vassilopoulou, V., Rochet, M.-J., 2014. Discarded fish in European waters: general patterns and contrasts. ICES J. Mar. Sci. J. Cons. 71, 1235-1245. doi:10.1093/icesjms/fst030

Vaida, F., Blanchard, S., 2005. Conditional Akaike information for mixed-effects models. Biometrika 92, 351-370. doi:10.1093/biomet/92.2.351

Valentinsson, D., Ulmestrand, M., 2008. Species-selective Nephrops trawling: Swedish grid experiments. Fish. Res. 90, 109-117. doi:10.1016/j.fishres.2007.10.011

Wileman, D., Ferro, R., Fonteyne, R., Millar, R., 1996. Manual of methods of measuring the selectivity of towed fishing gears (ICES Cooperative Research Report No. 215). ICES, Copenhagen, Denmark.

\section{List of Figures}




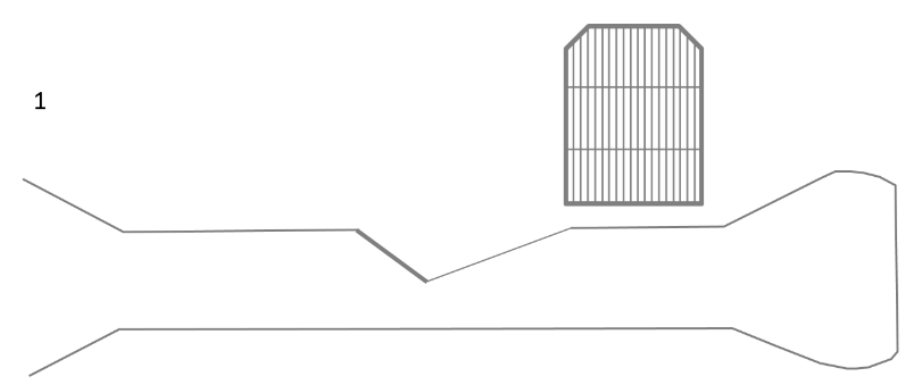

3

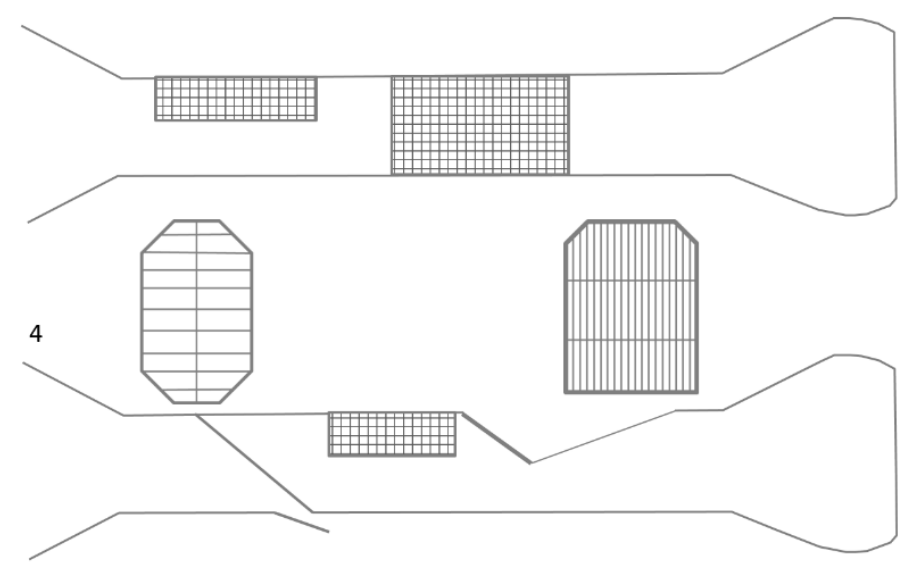

5

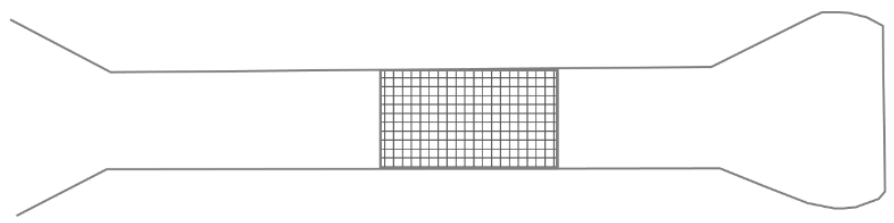

551

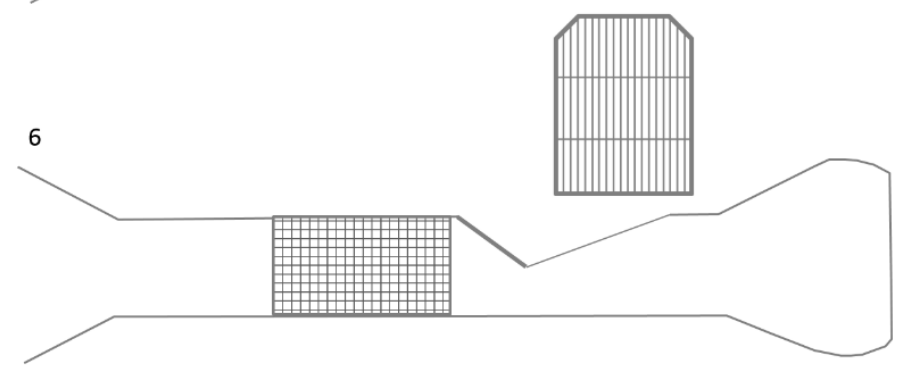

552 Figure 1. Schematic representation of the different selective devices tested which had an effect on the escape of whiting.

553 Gear reference as defined in Table 1 is used to identify each configuration. 

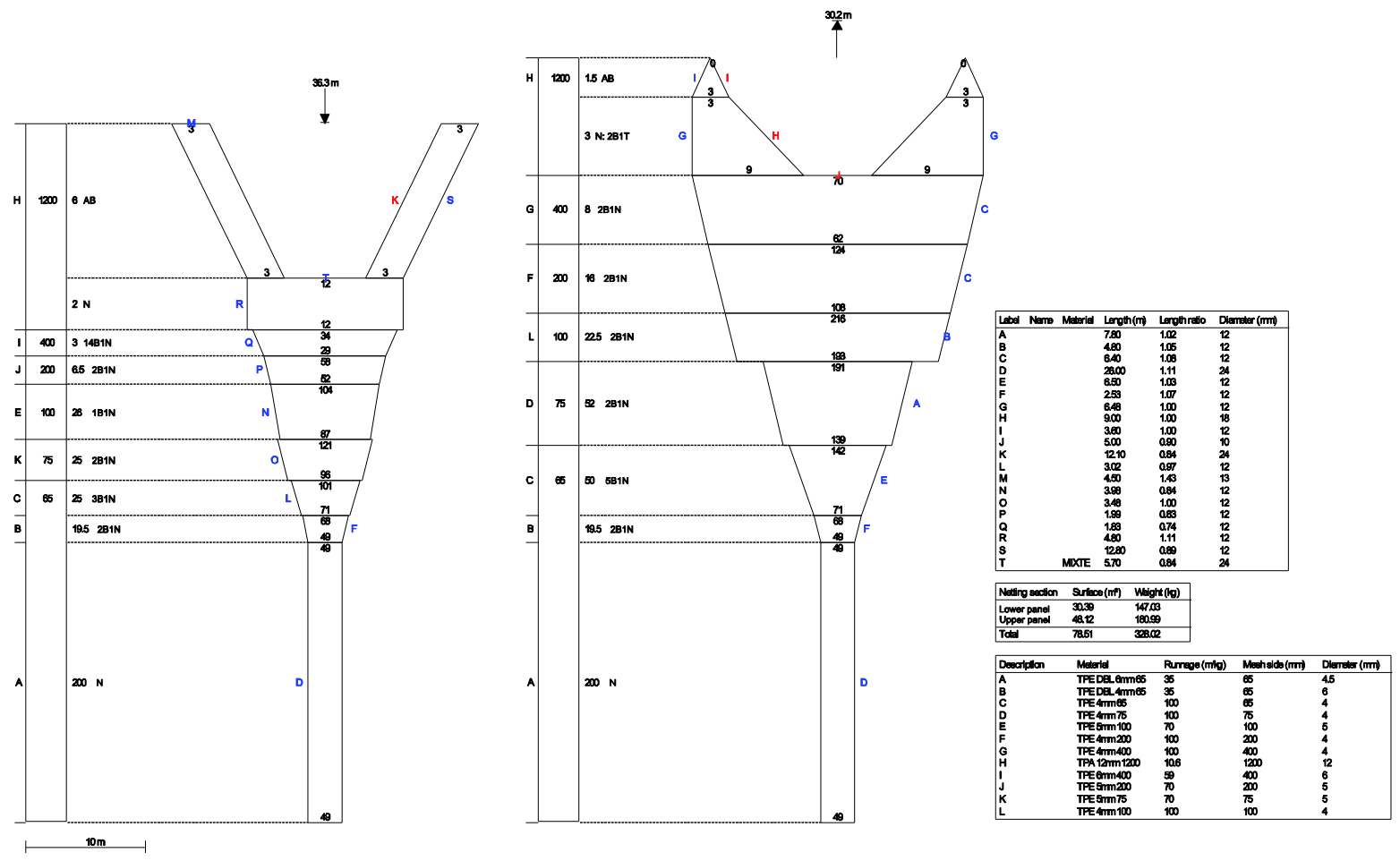

Figure 2. Design details of the large mesh trawl (Gear 2).
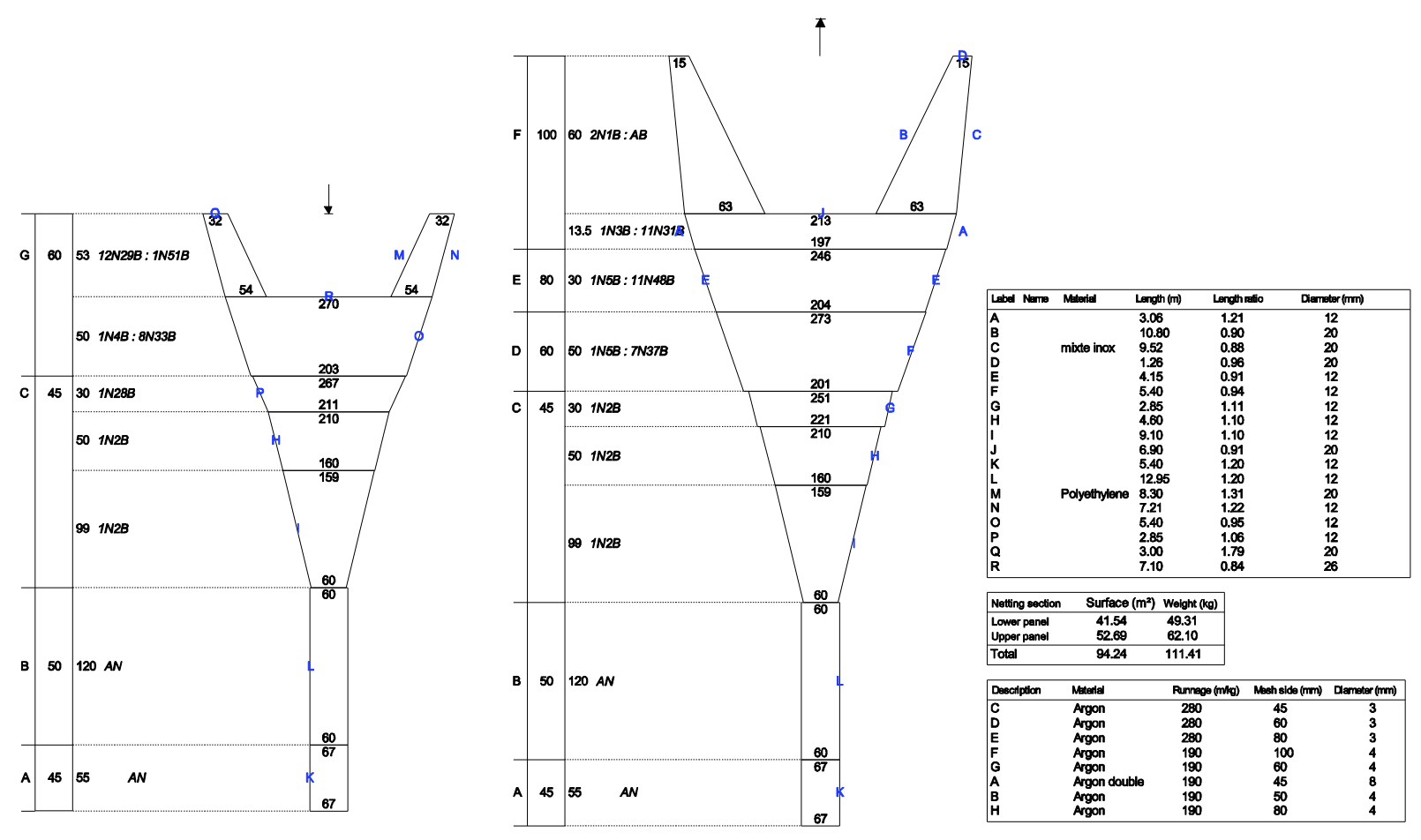

Figure 3. Control trawl design for vessels 16-20 m. 


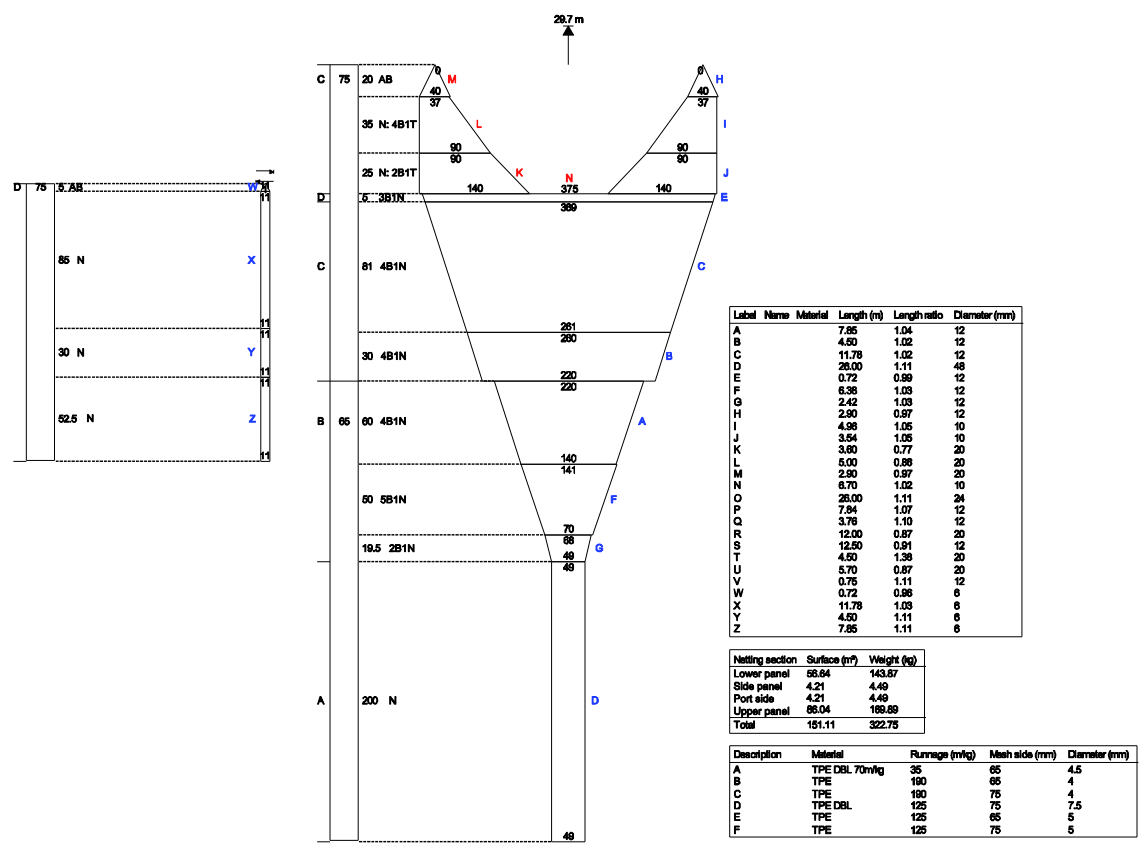

Figure 4. Control trawl design for vessels 20-24 m 

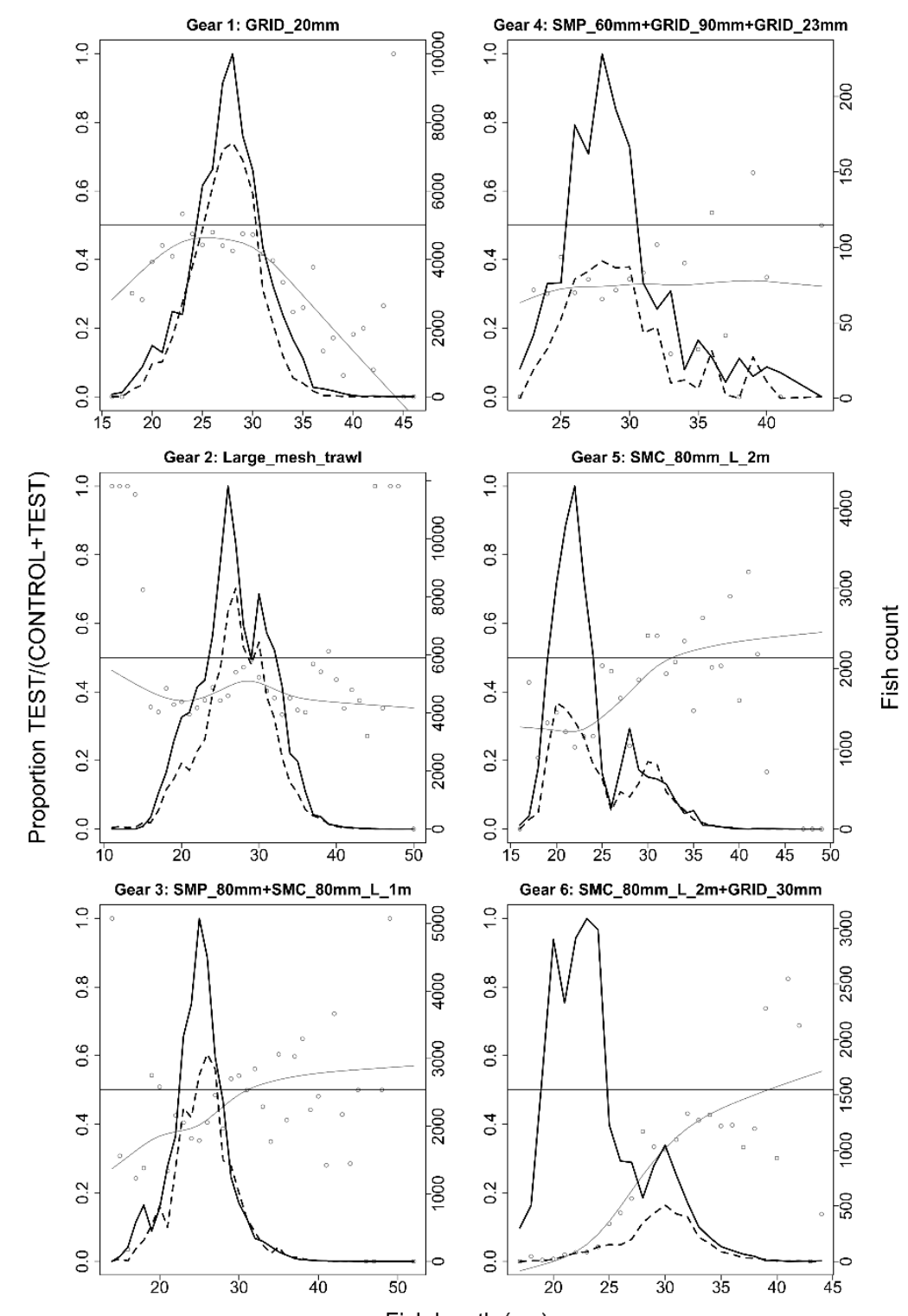

560

Fish length $(\mathrm{cm})$

561 Figure 5. Pooled upscaled catches of whiting from the selective devices tested on board 20-24 m long vessels (left-hand side, gears 1 to 3) and 16-20 m long vessels (right-hand side, gears 4 to 6). Catches from the control gear (thick black line), catches from the test gear (thick broken line), proportions (dots) and a regressive spline with four degrees of freedom ran on weighted proportions (thin black line) are shown. Each graph is labelled with reference number and a description of the tested gear. 

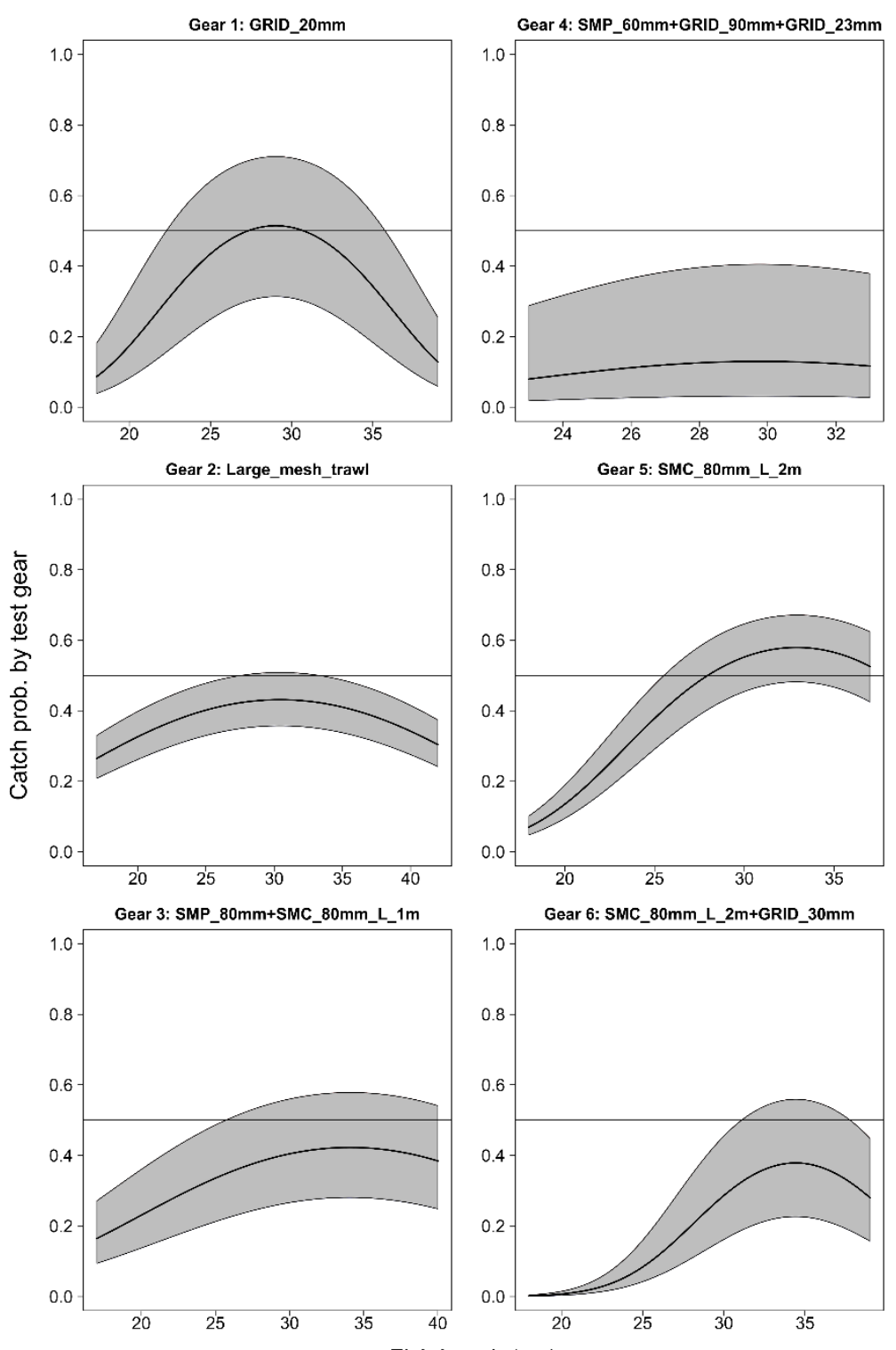

Fish length $(\mathrm{cm})$

567 Figure 6. GLMM output representing catch probability by test gear for the efficient selective devices on board 20-24 $\mathrm{m}$ long vessels (left-hand side, gears 1 to 3 ) and on board 16-20 m long vessels (right-hand side, gears 4 to 6 ), with $95 \%$ confidence intervals around the mean. 


\section{List of Tables}

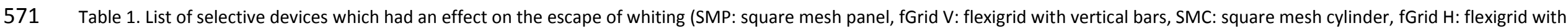

572 horizontal bars, aGrid V: aluminium grid with vertical bars, NA: not applicable or not available).

\begin{tabular}{|c|c|c|c|c|c|c|c|}
\hline Gear & Selective Device & Mesh size or bar spacing & Selective device dimensions & $\begin{array}{l}\text { Distance to } \\
\text { codline }\end{array}$ & $\begin{array}{l}\text { Date of sea } \\
\text { trials }\end{array}$ & $\begin{array}{l}\text { Area of sea } \\
\text { trials }\end{array}$ & $\begin{array}{l}\text { Number of } \\
\text { valid tows }\end{array}$ \\
\hline \multicolumn{8}{|c|}{ 20-24 m long vessels } \\
\hline 1 & fGrid V & $20 \mathrm{~mm}$ & $1.25 \mathrm{~m} * 0.745 \mathrm{~m}$ & NA & Feb 2009 & ICES IVC & 13 \\
\hline 2 & Large mesh trawl & & NA & NA & Jan 2010 & ICES IVC & 38 \\
\hline 3 & $S M P+S M C$ & $80 \mathrm{~mm} / 80 \mathrm{~mm}$ & $3 m * 1 m / 1 m$ & $12 \mathrm{~m} / 11 \mathrm{~m}$ & Apr 2013 & ICES IVc, VIId & 15 \\
\hline \multicolumn{8}{|c|}{ 16-20 m long vessels } \\
\hline 4 & $\begin{array}{l}\text { SMP + fGrid H + } \\
\text { fGrid V }\end{array}$ & $60 \mathrm{~mm} / 90 \mathrm{~mm} / 23 \mathrm{~mm}$ & $\begin{array}{l}0.76 \mathrm{~m} * 0.72 \mathrm{~m} / 1.40 \mathrm{~m} * 0.76 \mathrm{~m} / \\
1.25 \mathrm{~m} * 0.745 \mathrm{~m}\end{array}$ & NA & Jun 2010 & ICES VIId & 18 \\
\hline 5 & SMC & $80 \mathrm{~mm}$ & $2 \mathrm{~m}$ & & Nov 2013 & ICES VIId & 13 \\
\hline 6 & $\mathrm{SMC}+\mathrm{aGrid} \mathrm{V}$ & $80 \mathrm{~mm} / 80 \mathrm{~mm} / 30 \mathrm{~mm}$ & $3 \mathrm{~m} * 1 \mathrm{~m} / 2 \mathrm{~m} / 1.20 \mathrm{~m}^{*} 0.68 \mathrm{~m}$ & & Nov 2013 & ICES VIId & 21 \\
\hline
\end{tabular}

573

574 


\begin{tabular}{|c|c|c|c|c|c|c|c|}
\hline \multirow[t]{2}{*}{ Gear } & \multirow[t]{2}{*}{ Selective device } & \multicolumn{2}{|c|}{ Test gear } & \multicolumn{2}{|c|}{ Control gear } & \multicolumn{2}{|c|}{ K-S test } \\
\hline & & $\mathrm{L}-$ mean $(\mathrm{cm})$ & L-sd & $\mathrm{L}-$ mean $(\mathrm{cm})$ & L-sd & $D$ & $p$-value \\
\hline \multicolumn{8}{|c|}{$20-24 \mathrm{~m}$ long vessels } \\
\hline 1 & fGrid V (sp: $20 \mathrm{~mm}$ ) & 27.25 & 3.19 & 27.51 & 3.65 & 0.22 & 0.41 \\
\hline 2 & Large mesh trawl & 27.03 & 4.46 & 26.9 & 4.6 & 0.15 & 0.75 \\
\hline 3 & $\mathrm{SMP}(80 \mathrm{~mm})+\mathrm{SMC}(80 \mathrm{~mm}, \mathrm{~L}=1 \mathrm{~m})$ & 25.63 & 3.61 & 25 & 3.52 & 0.11 & 0.98 \\
\hline \multicolumn{8}{|c|}{ 16-20 m long vessels } \\
\hline 4 & SMP (60mm) + fGrid H (sp: $90 \mathrm{~mm})+$ fGrid V (sp: $23 \mathrm{~mm})$ & 29.16 & 3.87 & 29.03 & 3.87 & 0.33 & 0.19 \\
\hline 5 & $\mathrm{SMC}(80 \mathrm{~mm}, \mathrm{~L}=2 \mathrm{~m})$ & 24.71 & 4.82 & 23.34 & 4.05 & 0.19 & 0.61 \\
\hline 6 & SMC (80mm, L=2 m) + aGrid V (sp: $30 \mathrm{~mm})$ & 29.54 & 3.68 & 23.88 & 4.13 & 0.5 & $0.002 * * *$ \\
\hline
\end{tabular}

577

578 Table 3. GLMM parameter estimates for quadratic models fitted to the chosen selective devices (GR: gear ref., L: length, fGrid: flexigrid, sp: bar spacing, aGrid: aluminium grid).

\begin{tabular}{|c|c|c|c|c|}
\hline Gear & Selective device & Parameter & Estimate & Std. error \\
\hline \multicolumn{5}{|c|}{ 20-24 m long vessels } \\
\hline \multirow[t]{3}{*}{1} & fGrid V (sp: $20 \mathrm{~mm}$ ) & Intercept $\left(\beta_{0}\right)$ & 0.045 & 0.4203 \\
\hline & & STD Length $\left(\beta_{1}\right)$ & -0.104 & 0.0088 \\
\hline & & (STD Length) $)^{2}\left(\beta_{2}\right)$ & -0.214 & 0.0061 \\
\hline \multirow[t]{3}{*}{2} & Large mesh trawl & Intercept $\left(\beta_{0}\right)$ & -0.277 & 0.1551 \\
\hline & & STD Length $\left(\beta_{1}\right)$ & 0.0049 & 0.0032 \\
\hline & & (STD Length) $)^{2}\left(\beta_{2}\right)$ & -0.0635 & 0.0021 \\
\hline \multirow[t]{3}{*}{3} & $\mathrm{SMP}(80 \mathrm{~mm})+\mathrm{SMC}(80 \mathrm{~mm}, \mathrm{~L}=1 \mathrm{~m})$ & Intercept $\left(\beta_{0}\right)$ & -0.410 & 0.3137 \\
\hline & & STD Length $\left(\beta_{1}\right)$ & 0.151 & 0.0081 \\
\hline & & (STD Length) $)^{2}\left(\beta_{2}\right)$ & -0.058 & 0.0052 \\
\hline
\end{tabular}


16-20 $\mathrm{m}$ long vessels

4 SMP $(60 m m)+$ fGrid H (sp: $90 \mathrm{~mm})+$ fGrid $\mathrm{V}$ (sp: $23 \mathrm{~mm}$ )

Intercept $\left(\beta_{0}\right)$

Length $\left(\beta_{1}\right)$

Length $^{2}\left(\beta_{2}\right)$

Intercept $\left(\beta_{0}\right)$

Length $\left(\beta_{1}\right)$

Length $^{2}\left(\beta_{2}\right)$

Intercept $\left(\beta_{0}\right)$

Length $\left(\beta_{1}\right)$

Length $^{2}\left(\beta_{2}\right)$

$\begin{array}{rr}-1.917 & 0.759 \\ 0.061 & 0.038 \\ -0.068 & 0.026 \\ 0.11 & 0.1964 \\ 0.42 & 0.0130 \\ -0.22 & 0.0095 \\ -1.04 & 0.3661 \\ 0.85 & 0.0084 \\ -0.33 & 0.0062\end{array}$

579 